\title{
Faktor-Faktor Dalam Menggunakan E-Money (Gopay) pada Masyarakat Muslim di Kota Semarang
}

\author{
Muhammad Faizun Ulurrosyad ${ }^{1}$, Prabowo Yudo Jayanto ${ }^{2}$ \\ ${ }^{1}$ Program Studi Akuntansi \\ Universitas Negeri Semarang \\ Kampus Sekaran Gunungpati, Semarang, Indonesia \\ e-mail: ${ }^{1}$ m.faizun45@gmail.com \\ ${ }^{2}$ Program Studi Akuntansi \\ Universitas Negeri Semarang \\ Kampus Sekaran Gunungpati, Semarang, Indonesia \\ e-mail: ${ }^{2}$ m.faizun45@gmail.com

\begin{tabular}{ccc} 
Diterima & Direvisi & Disetujui \\
$03-02-2020$ & $17-02-2020$ & $18-03-2020$ \\
\hline
\end{tabular}

\begin{abstract}
Abstrak - Gerakan Nasional Non Tunai (GNNT) telah dicanangkan oleh Bank Indonesia sejak 2014 melalui sosialisasinya. Hal tersebut membuat penggunaan e-money di Indonesia terus berkembang. Perkembangan emoney semakin meningkat dengan adanya dukungan dari pemerintah yaitu banyaknya fasilitas publik yang terintegrasi langsung dengan e-money, salah satunya adalah Gopay. Berdasarkan penelitian yang dirilis oleh YouGov, Gopay menjadi mobile payment (uang elektronik) yang penggunaannya paling tinggi di Indonesia yaitu mencapai 80\%. Tujuan penelitian ini adalah untuk mengetahui pengaruh dari persepsi manfaat, kemudahan, risiko, transparansi dan akuntabilitas terhadap penggunaan E-Money (Gopay) pada masyarakat muslim di Kota Semarang. Populasi dalam penelitian ini adalah masyarakat muslim di kota Semarang. Teknik sampling yang digunakan adalah teknik accidental sampling dan jumlah sampel dari penelitian ini adalah 100 responden. Pengumpulan data primer menggunakan metode kuesioner. Data dianalisis menggunakan analisis deskriptif dan Structural Equation Modelling (SEM) berbasis PLS dengan alat analisis SmartPLS 3.0. Hasil dari penelitian ini adalah persepsi manfaat, persepsi kemudahan, dan transparansi berpengaruh positif terhadap minat menggunakan E-Money Gopay, sedangkan untuk risiko berpengaruh negatif terhadap minat menggunakan $E$ Money Gopay. Untuk akuntabilitas tidak memiliki pengaruh terhadap minat menggunakan E-Money Gopay. Simpulan dari penelitian ini menunjukan bahwa minat menggunakan e-money dipengaruhi oleh persepsi manfaat, kemudahan, risiko dan transparansi. Sedangkan untuk akuntabilitas tidak berpengaruh terhadap minat menggunakan e-money.
\end{abstract}

Kata Kunci: Minat Menggunakan E-Money; Persepsi Manfaat; Persepsi Kemudahan

\begin{abstract}
The National Non-Cash Movement (GNNT) has been launched by Bank Indonesia since 2014 through its socialization. This makes the use of e-money in Indonesia continues to grow. The development of e-money is increasing with the support of the government, namely the number of public facilities that are integrated directly with e-money, one of which is Gopay. Based on research released by YouGov, Gopay became the highest mobile payment (electronic money) in Indonesia, reaching 80\%. The purpose of this study was to determine the effect of perceived benefits, convenience, risk, transparency and accountability on the use of E-Money (Gopay) in Muslim communities in the city of Semarang. The population in this study are the Muslim community in the city of Semarang. The sampling technique used was accidental sampling technique and the number of samples from this study were 100 respondents. Primary data collection using the questionnaire method. Data were analyzed using descriptive analysis and PLS-based Structural Equation Modeling (SEM) with the SmartPLS 3.0 analysis tool. The results of this study are the perception of benefits, perceived convenience, and transparency have a positive effect on the interest in using E-Money Gopay, while for the risk of a negative effect on the interest in using EMoney Gopay. For accountability does not have an influence on interest in using E-Money Gopay. The conclusion from this study shows that the interest in using e-money is influenced by the perception of benefits, convenience, risk and transparency. As for accountability does not affect the interest in using e-money.
\end{abstract}

Keywords: Interest in Using E-Money; Benefit Perception; Ease Perception; Risk Perception; Transparency; Accountability. 


\section{PENDAHULUAN}

Sistem pembayaran tidak dapat dipisahkan dari perkembangan uang yang diawali dari pembayaran secara tunai sampai kepada elektronik yang bersifat nontunai (Subari \& Ascarya, 2003). Perkembangan sistem pembayaran didorong oleh semakin besarnya volume dan nilai transaksi, peningkatan risiko, kompleksnya transaksi, dan perkembangan teknologi. Sistem pembayaran tunai berkembang dari commodity money sampai fiat money, sementara sitem pembayaran nontunai berkembang dari yang berbasis warkat (cek, bilyet giro, dan sebagainya) sampai kepada yang berbasis elektronik (kartu dan electronic money).

Gerakan Nasional Non Tunai (GNNT) telah dicanangkan oleh Bank Indonesia sejak 2014 melalui sosialisasinya. Hal tersebut membuat penggunaan e-money di Indonesia terus berkembang. Perkembangan e-money semakin meningkat dengan adanya dukungan dari pemerintah yaitu banyaknya fasilitas publik (transportasi, tol, parkir) yang terintegrasi langsung dengan e-money. Bahkan uang elektronik sudah menjalar ke berbagai instansi seperti pendidikan. Di dunia pendidikan aplikasi e-money biasanya dalam bentuk kartu mahasiswa, atau kartu khusus yang dapat digunakan dalam transaksi di wilayah institusi terkait (Utami \& Kusumawati, 2017).

Berdasarkan penelitian yang dirilis oleh YouGov (2019), Gopay menjadi mobile payment (uang elektronik) yang penggunaannya paling tinggi di Indonesia yaitu mencapai $80 \%$. Tingginya penggunaan e-money oleh masyarakat dikarenakan banyaknya kemudahan yang bisa didapatkan oleh pengguna e-money. Beberapa keuntungan dalam menggunakan e-money adalah, pertama, memberikan kemudahan dalam transaksi pembayaran secara cepat dan aman bagi masyarakat luas. Kedua, masalah cash handling dapat dipecahkan yang selama ini sering dialami ketika menggunakan uang tunai sebagai pembayaran bagi industri. Ketiga, meningkatkan efisiensi percetakan uang dan penggandaan uang bagi bank Indonesia.

Variabel dalam penelitian ini diambil dari penelitian terdahulu yang tidak konsisten. Ramadhan dkk (2016) menemukan bahwa variabel manfaat tidak berpengaruh terhadap minat menggunakan $e$ money. Namun dalam penelitian yang dilakukan Djamaluddin dkk (2016) menemukan hasil bahwa manfaat berpengaruh positif terhadap niat menggunakan e-money. Utami \& Kusumawati (2017) dan Arvidsson (2014) alam penelitiannya menunjukan hasil bahwa kemudahan berpengaruh positif terhadap minat menggunakan e-money, sedangkan hasil penelitian yang dilakukan oleh Fong (2016) yaitu kemudahan tidak berpengaruh terhadap niat perilaku. Ozturk (2016) serta Wu et., al. (2017) membuktikan bahwa adanya hubungan negatif dan signifikan antara persepsi risiko dengan niat menggunakan e-money. Namun hasil penelitian dari Teoh et,. al. (2013) menyatakan bahwa persepsi risiko tidak mempengaruhi niat menggunakan $e$ money secara signifikan.Variabel transparansi dan akuntabilitas dipilih karena masih jarang yang meneliti terkait hubungannya dengan minat menggunakan $e$-money.

Tujuan dari penelitian ini adalah untuk menganalisis pengaruh persepsi manfaat, kemudahan, risiko akuntabilitas dan transparansi terhadap minat menggunakan e-money pada masyarakat muslim di kota Semarang. Orisinalitas dalam penelitian ini adalah adanya variabel akuntabilitas dan transparansi sebagai variabel baru yang akan diuji. Selain itu perbedaan penelitian ini dengan penelitian sebelumnya adalah penelitian ini menggunakan analisis Smart-Partial Least Square (Smart-PLS) dengan alat analisis Smart-PLS. Selain itu adanya perbedaan objek penelitian dari penelitian yang sebelumnya dimana mayoritas penelitian sebelumnya tidak menyebutkan secara spesifik jenis E-Money. Objek penelitian yang digunakan dalam penelitian ini yaitu masyarakat muslim pengguna $E$ Money Gopay di Kota Semarang.

Penelitian mengenai minat menggunakan emoney atau perilaku masyarakat didukung oleh teori Theory of Planned Behaviour (TPB). Minat menggunakan e-money dapat dipengaruhi oleh beberapa faktor yang dapat dijelaskan oleh teori ini. Teori ini dikembangkan oleh Ajzen (1991) menjelaskan bahwa sikap (attitude) dan kepercayaan (belief) konsumen dapat mempengaruhi perilaku konsumen dalam menerima atau menolak produk sistem informasi. Hubungan Theory of Planned Behaviour (TPB) dalam penelitian ini karena dalam TPB menjelaskan jika terdapat faktor sebagai dasar hubungan terkait seorang individu memiliki niat dalam penggunaan sistem, yaitu Attitude toward the behavior. Faktor Attitude toward the behaviour menjelaskan sikap individu mengadopsi sesuatu sistem yang dianggapnya positif maka hal tersebut akan dipilih untuk berperilaku dalam kehidupannya. Selain itu penelitian ini juga mengkaji teori Innovation Diffusion Theory (IDT). Teori ini menjelaskan bahwa setiap individu mempunyai level yang berbeda-beda dalam keinginan mengadopsi produk atau layanan inovasi. Level risiko menjadi salah satu hal yang dipertimbangkan oleh induvidu dalam mengadopsi produk atau layanan.

Penelitian ini juga mencoba untuk mengkaji teori atribusi. Robbins \& Judge (2008) menyatakan bahwa ketika individu-individu mengamati perilaku seseorang, individu tersebut berupaya untuk menentukan apakah perilaku tersebut disebabkan secara internal atau eksternal. Teori atribusi relevan untuk membahas tentang upaya-upaya yang dilakukan sehingga memahami penyebab-penyebab 
perilaku kita dan orang lain. Maka, definisi atribusi berarti upaya untuk memahami penyebab dibalik perilaku orang lain atau konsumen, dan dalam beberapa kasus juga penyebab di balik perilaku kita sendiri. Hubungan teori atribusi dalam penelitian ini relevan dengan variabel yang akan diteliti transparansi dan akuntabilitas karena faktor tersebut muncul dari eksternal konsumen Gopay.

Davis (1989) mendefinisikan persepsi manfaat/kegunaan (perceived usefulness) sebagai keyakinan akan kemanfaatan, yaitu tingkatan dimana user percaya bahwa penggunaan teknologi/sistem akan meningkatkan peforma mereka dalam bekerja. Manfaat dari e-money dapat mempengaruhi minat menggunakan e-money. Manfaat yang dapat diterima oleh pengguna emoney dapat meningkatkan minat masyarakat untuk menggunakan e-money. Hal ini sesuai dengan teori Theory of Planned Behaviour (TPB), karena dalam TPB menjelaskan jika terdapat faktor sebagai dasar hubungan terkait seorang individu memiliki niat dalam penggunaan sistem, yaitu Attitude toward the behavior. Faktor Attitude toward the behaviour menjelaskan sikap individu mengadopsi sesuatu sistem yang dianggapnya positif maka hal tersebut akan dipilih untuk berperilaku dalam kehidupannya. Hal tersebut sesuai dengan varibel dalam penelitian ini yaitu persepsi kegunaaan/manfaat. Dapat dikatakan seseorang akan menggunakan e-money pada saat mereka merasa dan percaya bahwa $e$ money memiliki kemanfaatan serta dapat meningkatkan kinerjanya.

Penelitian Djamaluddin et., al. (2016) menemukan hasil bahwa manfaat berpengaruh positif terhadap niat menggunakan $e$-money. Oleh karena itu, dapat disimpulkan bahwa manfaat berpengaruh positif terhadap minat menggunakan $e$ money.

\section{H1 : Manfaat berpengaruh positif terhadap minat menggunakan $e$-money (GoPay)}

Percieved ease of use diartikan sebagai

keyakinan akan kemudahan penggunaan, yaitu tingkatan dimana user percaya bahwa teknologi/sistem tersebut dapat digunakan dengan mudah dan bebas dari masalah (Davis, 1989). Pengguna teknologi mempercayai bahwa sistem layanan e-money Gopay mudah dipahami dan mudah dioperasikan. Pengguna juga mempercayai penggunaan Gopay dapat mengurangi tenaga dan waktu disaat melakukannya transaksi. Kemudahan sistem dalam bertransaksi menggunakan layanan uang elektronik yang sudah disediakan oleh pihak Gojek bertujuan untuk memudahkan para penggunanya. Teori Theory of Planned Behaviour (TPB) menjelaskan bahwa sikap individu mengadopsi sesuatu sistem yang dianggapnya positif maka hal tersebut akan dipilih untuk berperilaku dalam kehidupannya. Kemudahan yang ditawarkan oleh e-money dapat membuat seseorang untuk menggunakan $e$-money.
Utami \& Kusumawati (2017) dan Arvidsson (2014) dalam penelitiannya menunjukan hasil bahwa kemudahan berpengaruh positif terhadap minat menggunakan $e$-money. Oleh karena itu, dapat disimpulkan bahwa kemudahan berpengaruh positif terhadap minat menggunakan $e$ money.

H2: Kemudahan berpengaruh positif terhadap minat menggunakan E-Money (GoPay).

Risiko adalah persepsi yang mencerminkan perasaan ketidakpastian seseorang di kalangan konsumen mengenai kemungkinan konsekuensi negatif dari penggunaan tekonologi baru yang menghalangi adopsi (Fong, 2016). Risiko dipersepsikan dapat memengaruhi niat seseorang untuk menggunakan layanan $\boldsymbol{e}$-money karena mereka cenderung tidak terlibat dalam transaksi e-money jika mereka menganggap jenis layanan ini melibatkan tingkat risiko yang tinggi. Penelitian Schierz et., al. (2010) menemukan bahwa konsumen kurang termotivasi untuk mengadopsi metode pembayaran baru jika mereka berpikir ada risiko yang lebih besar dalam mengadopsinya daripada metode pembayaran yang ada. Dalam proses keputusan inovasi teori Innovation Diffusion Theory (IDT), risiko yang dirasakan diperdebatkan sebagai penentu kritis terutama dalam tahap pra-adopsi teknologi ketika orang tidak memiliki pengalaman dengan itu dan waspada terhadap risiko dan konsekuensi dari penggunaannya. Level risiko menjadi salah satu hal yang dipertimbangkan oleh induvidu dalam mengadopsi produk atau layanan. Maka dari itu persepsi risiko dapat mempengaruhi tingkat penggunaan teknologi baru seperti e-money. Semakin tinggi tingkat risiko pada E-Money Gopay maka semakin rendah minat masyarakat untuk menggunakan E-Money Gopay.

Penelitian yang dilakukan oleh Fong (2016) menjelaskan bahwa risiko berpengaruh kecil terhadap niat perilaku masyarakat menggunakan $e$ money Oleh karena itu, dapat disimpulkan bahwa risiko berpengaruh negatif terhadap minat menggunakan $e$-money.

H3: Risiko berpengaruh negatif terhadap minat menggunakan E-Money (GoPay).

Akuntabilitas (accountability) dapat dipahami sebagai suatu kewajiban pihak pemegang amanah (agent) untuk memberikan pertanggungjawaban, menyajikan, melaporkan dan mengungkapkan segala aktifitas dan kegiatan yang menjadi tanggungjawabnya kepada pihak pemberi amanah (principal) yang memiliki hak dan kewenangan untuk meminta pertanggungjawaban tersebut (Mardiasmo, 2002). Akuntabilitas merupakah salah satu dari prinsip dasar good corporate governanve. Akuntabilitas yang dimaksudkan adalah mencari informasi atau jawaban terkait dengan pertanggungjawaban atas segala yang telah dilakukan dan harus sesuai dengan yang sebenarnya terjadi. Berdasarkan teori atribusi yang 
menjelaskan bahwa perilaku seorang individu disebabkan dari internal atau eksternal. Akuntabilitas adalah bagian dari faktor eksternal yang mempengaruhi minat konsumen untuk menggunakan produk. Minat konsumen akan meningkat jika perusahaan menerapkan akuntabilitas dalam sistem layanan Gopay.

Oleh karena itu, dapat disimpulkan bahwa akuntabilitas berpengaruh positif terhadap minat menggunakan $e$-money.

\section{H4: Akuntabilitas berpengaruh positif terhadap minat menggunakan E-Money (GoPay).}

Transparansi adalah suatu proses keterbukaan dari para pengelola manajemen, utamanya manajemen publik, untuk membangun akses dalam proses pengelolaannya sehingga arus informasi keluar dan masuk secara berimbang. Transparansi dibangun atas dasar kebebasan memperoleh informasi. Informasi yang berkaitan dengan kepentingan publik secara langsung dapat diperoleh oleh mereka yang membutuhkan (Bayinah \& Bahri, 2018). Transparansi yang dimaksudkan dalam penelitian ini adalah memberikan informasi transaksi yang terbuka, jujur, dan tidak diskriminatif kepada masyarakat/konsumen berdasarkan pertimbangan bahwa konsumen memiliki hak untuk mengetahui secara terbuka dan menyeluruh atas pertanggungjawaban perusahaan dalam proses transaksi keuangan yang dipercayakan kepadanya. Transparansi dibutuhkan dalam pencatatan transaksi e-money untuk mencegah kesalahan transaksi. Berdasarkan teori atribusi yang menjelaskan bahwa perilaku seorang individu disebabkan dari internal atau eksternal. Transparansi adalah bagian dari faktor eksternal yang mempengaruhi minat konsumen. Minat konsumen akan meningkat jika perusahaan menerapkan transparansi dalam sistem layanan Gopay.

Oleh karena itu, dapat disimpulkan bahwa transparansi berpengaruh positif terhadap minat menggunakan $e$-money.

\section{H5: Transparansi berpengaruh positif terhadap} minat menggunakan E-Money (GoPay).

Berdasarkan uraian kerangka pemikiran teoritis dan pengembangan hipotesis di atas, maka penelitian ini menggunakan model kerangka pemikiran dijelaskan pada Gambar 1. sebagai berikut:

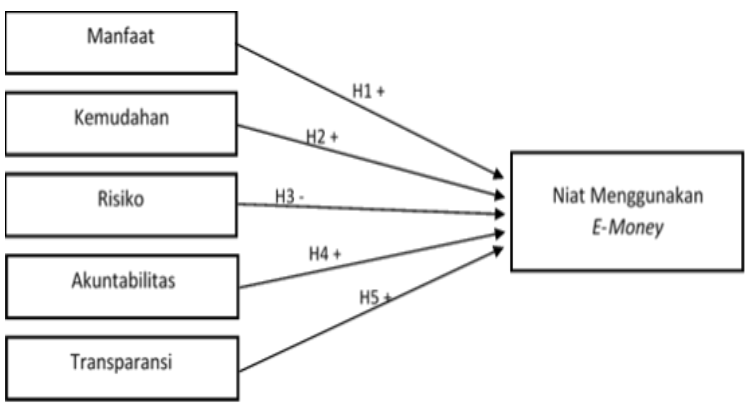

Sumber: Peneliti 2019

Gambar 1. Kerangka Berfikir

\section{METODOLOGI PENELITIAN}

Penelitian ini merupakan penelitian kuantitatif. Data yang digunakan dalam penelitian ini adalah data primer dengan metode pengumpulan data yaitu kuesioner. Pada penelitian ini menggunakan teknik analisis kuantitatif deskripsi yaitu stastistik yang digunakan menganalisis data dengan cara mendeskripsikan yang sudah terkumpul. Berdasarkan data dari BPS Kota Semarang pada tahun 2019 terdapat 1.509.602 jiwa penduduk muslim di kota Semarang yang menjadi populasi dalam penelitian ini. Sampel yang digunakan dalam penelitian ini adalah 100 responden. Penentuan jumlah responden dihitung dengan menggunakan rumus slovin dengan tingkat signifikansi $10 \%$. Kriteria untuk pengambilan sampel dengan menggunakan teknik sampling seadanya (Accidental Sampling), yaitu pengambilan sampel dengan ditentukan seadanya atau secara sembarang, asalkan yang bersangkutan memiliki karakteristik, data, atau informasi yang dibutuhkan dalam penelitian. Kriteria yang ditentukan yaitu responden sudah atau pernah menggunakan Gopay untuk bertransaksi, responden berasal atau sedang berada di Kota Semarang, serta responden pengguna Gopay adalah beragama muslim. Definisi dan indikator pengukuran tiap variabel dalam penelitian ini sijelaskan pada Tabel 1 berikut ini :

Tabel 1. Definisi Operasional Variabel Penelitian

\begin{tabular}{|c|c|c|}
\hline No & Definisi & Inc \\
\hline 1 & $\begin{array}{l}\text { Minat Menggunakan E- } \\
\text { Money (Y) } \\
\text { Minat menggunakan } \\
\text { adalah keinginan atau } \\
\text { ketertarikan pada suatu } \\
\text { hal yang baik benda } \\
\text { maupun aktivitas yang } \\
\text { sesuai dengan perasaaan } \\
\text { individu atau seseorang } \\
\text { tersebut sebagai sumber } \\
\text { motivasi (Djamaluddin et } \\
\text { al., 2016) }\end{array}$ & $\begin{array}{l}\text { 1. Manfaat } \\
\text { 2. Kemudahan } \\
\text { 3. Keamanan } \\
\text { 4. Ketertarikan } \\
\text { (Utami \& } \\
\text { Kusumawati, 2017) }\end{array}$ \\
\hline 2 & $\begin{array}{l}\text { Manfaat (X1) } \\
\text { Kegunaan adalah sejauh } \\
\text { mana seseorang meyakini } \\
\text { bahwa penggunaan } \\
\text { sistem informasi tertentu } \\
\text { akan meningkatkan } \\
\text { kinerjanya (Utami \& } \\
\text { Kusumawati, 2017) }\end{array}$ & $\begin{array}{l}\text { 1. Efektivitas } \\
\text { 2. Efisiensi } \\
\text { 3. Minimalisir } \\
\quad \text { kesalahan } \\
\text { 4. Kebanggaan } \\
\text { (Utami \& } \\
\text { Kusumawati, 2017) }\end{array}$ \\
\hline 3 & $\begin{array}{lr}\text { Kemudahan (X2) } \\
\text { Kemudahan adalah } \\
\text { sejauh mana seseorang } \\
\text { yakin } & \text { bahwa } \\
\text { menggunakan } & \text { sistem } \\
\text { teknologi tertentu tidak } \\
\text { memerlukan usaha yang }\end{array}$ & $\begin{array}{l}\text { 1. Kemudahan } \\
\text { menemukan } \\
\text { tempat } \\
\text { penggunaan } \\
\text { 2. Kemudahan } \\
\text { dalam }\end{array}$ \\
\hline
\end{tabular}




\begin{tabular}{|c|c|c|}
\hline No & Definisi & Indikator \\
\hline & $\begin{array}{l}\text { lebih atau dengan kata } \\
\text { lain mudah dan terbebas } \\
\text { dari masalah atau } \\
\text { hambatan (Davis, 1989) }\end{array}$ & $\begin{array}{l}\text { penggunaan } \\
\text { 3. Kemudahan } \\
\text { memperoleh } \\
\text { bantuan } \\
\text { (Djamaluddin et al., } \\
\text { 2016) }\end{array}$ \\
\hline 4 & $\begin{array}{l}\text { Risiko (X3) } \\
\text { Risiko adalah konstruk } \\
\text { yang mencerminkan } \\
\text { perasaan ketidakpastian } \\
\text { seseorang mengenai } \\
\text { kemungkinan } \\
\text { konsekuensi negatif dari } \\
\text { penggunaan teknologi } \\
\text { baru yang dapat } \\
\text { menghalanginya untuk } \\
\text { penggunaan (Fong, 2016) }\end{array}$ & $\begin{array}{l}\text { 1. Berisiko } \\
\text { 2. Kerugian } \\
\text { 3. Ketidakpastian } \\
\text { 4. Kemasalahan } \\
\text { (Fong, 2016) }\end{array}$ \\
\hline 5 & $\begin{array}{l}\text { Akuntabilitas (X4) } \\
\text { Akuntabilitas adalah } \\
\text { sebagai sebuah kejelasan } \\
\text { fungsi, struktur, sistem } \\
\text { dan pertanggungjawaban } \\
\text { organ perusahaan } \\
\text { sehingga pengelolaan } \\
\text { perusahaan terlaksana } \\
\text { secara efektif. (Kaihatu, } \\
\text { 2006) }\end{array}$ & $\begin{array}{l}\text { 1. Kepatuhan } \\
\text { terhadap prosedur } \\
\text { 2. Pelayanan yang } \\
\text { responsif } \\
\text { 3. Pelayanan yang } \\
\text { cermat } \\
\text { 4. Pelayanan } \\
\text { dengan biaya } \\
\text { murah } \\
\text { (Mahmudi, 2013) }\end{array}$ \\
\hline 6 & $\begin{array}{l}\text { Transparasi (X5) } \\
\text { Transparansi adalah suatu } \\
\text { proses keterbukaan dari } \\
\text { para pengelola } \\
\text { manajemen, utamanya } \\
\text { manajemen publik, untuk } \\
\text { membangun akses dalam } \\
\text { proses pengelolaannya } \\
\text { sehingga arus informasi } \\
\text { keluar dan masuk secara } \\
\text { berimbang. } \\
\text { (Bayinah \& Bahri, 2018) }\end{array}$ & $\begin{array}{l}\text { 1. Terdapat } \\
\text { pengumuman } \\
\text { kebijakan } \\
\text { mengenai } \\
\text { pendapatan, } \\
\text { pengelolaan } \\
\text { keuangan dan } \\
\text { asset. } \\
\text { 2. Tersedia laporan } \\
\text { mengenai } \\
\text { pendapatan, } \\
\text { pengelolaan } \\
\text { keuangan dan } \\
\text { asset yang mudah } \\
\text { diakses. } \\
\text { 3. Tersedia laporan } \\
\text { pertanggungjawa } \\
\text { ban yang tepat } \\
\text { waktu. } \\
\text { 4. Tersedianya } \\
\text { sarana untuk } \\
\text { suara dan usulan } \\
\text { rakyat. } \\
\text { 5. Terdapat sistem } \\
\text { pemberian } \\
\text { informasi kepada } \\
\text { publik. } \\
\text { (Nasim } \\
\text { Romdhon, 2014) }\end{array}$ \\
\hline
\end{tabular}

Sumber: Peneliti (2019)
Jawaban diukur dengan menggunakan dengan skala likert, 1 (Sangat Tidak Setuju), 2 (Tidak Setuju), 3 (Setuju) dan 4 (Sangat Setuju). Penelitian ini menggunakan teknik analisis data statistik deskriptif dan inferensial dengan signifikansi $10 \%$. Alat analisis yang digunakan adalah Structural Equation Model-Partial Least Square (SEM-PLS) dengan alat analisis SmartPLS 3.0.

\section{HASIL DAN PEMBAHASAN}

Analisis SEM-PLS meliputi uji outer model atau measurement model yang didalamnya terdapat uji validitas dan uji reliabilitas. Kedua uji inner model atau model struktural yang menguji pengaruh variabel laten dengan variabel konstruknya. Berdasarkan hasil penelitian, nilai outer loadings dari penelitian ini menghasilkan nilai loading factor diatas 0,7 pada seluruh konstruk yang artinya telah memenuhi syarat validitas. Selain itu berdasarkan hasil output penelitian, nilai AVE 0,62 (lebih dari $0,5)$ hal ini berarti memenuhi syarat validitas.

\section{Tabel 2. Composite Reliability dan Cronbachs Alpha}

\begin{tabular}{|l|c|c|}
\hline \multicolumn{1}{|c|}{ Variabel } & $\begin{array}{c}\text { Cronbach's } \\
\text { Alpha }\end{array}$ & $\begin{array}{c}\text { Composite } \\
\text { Reliability }\end{array}$ \\
\hline Manfaat & 0,762 & 0,849 \\
\hline Kemudahan & 0,713 & 0,839 \\
\hline Risiko & 0,753 & 0,843 \\
\hline Akuntabilitas & 0,814 & 0,885 \\
\hline Transparansi & 0,716 & 0,814 \\
\hline $\begin{array}{l}\text { Minat menggunakan } \\
\text { E-Money Gopay }\end{array}$ & 0,802 & 0,870 \\
\hline
\end{tabular}

Sumber: Hasil Pengolahan Data SmaertPLS, 2019

Dalam PLS-SEM dengan menggunakan program SmartPLS 3.0, untuk mengukur reliabilitas suatu konstruk dengan indikator reflektif dapat dilakukan dengan du acara yaitu dengan melihat nilai Cronbach's Alpha dan Composite Reliability. Dari hasil olah data Tabel 2, menunjukkan bahwa nilai Cronbach's Alpha dan Composite Reliability seluruh konstruk diatas 0,70. Hal tersebut menunjukkan bahwa semua pernyataan yang digunakan untuk mengukur masing-masing konstruk adalah reliabel.

Uji inner model untuk menguji pengaruh variabel laten. Uji inner model dilihat dari nilai R2. Berdasarkan hasil output penelitian, variabel independen terhadap variabel dependen minat menggunakan e-money menunjukkan nilai R2 sebesar 0,612, yang berarti variabel dependen literasi keuangan syariah dijelaskan oleh variabel laten independen sebesar $61,2 \%$, sedangkan sisanya yaitu $38,8 \%$ dijelaskan oleh faktor atau kondisi lain yang tidak dijelaskan dalam model. 
Tabel 3. Ringkasan Pengujian Hipotesis

\begin{tabular}{|c|c|c|c|}
\hline Hipotesis & Pernyataan & $\begin{array}{c}T- \\
\text { Statistic }\end{array}$ & Hasil \\
\hline $\mathrm{H} 1$ & $\begin{array}{l}\text { Manfaat berpengaruh } \\
\text { positif terhadap minat } \\
\text { menggunakan E- } \\
\text { Money Gopay }\end{array}$ & 3,134 & Diterima \\
\hline $\mathrm{H} 2$ & $\begin{array}{l}\text { Kemudahan } \\
\text { berpengaruh positif } \\
\text { terhadap minat } \\
\text { menggunakan E- } \\
\text { Money Gopay }\end{array}$ & 2,687 & Diterima \\
\hline H3 & $\begin{array}{l}\text { Risiko berpengaruh } \\
\text { negatif terhadap minat } \\
\text { menggunakan E- } \\
\text { Money Gopay }\end{array}$ & 2,484 & Diterima \\
\hline $\mathrm{H} 4$ & $\begin{array}{l}\text { Akuntabilitas } \\
\text { berpengaruh positif } \\
\text { terhadap minat } \\
\text { menggunakan E- } \\
\text { Money Gopay }\end{array}$ & 0,912 & Ditolak \\
\hline H5 & $\begin{array}{l}\text { Transparansi } \\
\text { berpengaruh positif } \\
\text { terhadap minat } \\
\text { menggunakan E- } \\
\text { Money Gopay }\end{array}$ & 3,334 & Diterima \\
\hline
\end{tabular}

Sumber: Output SmartPLS 3.0, 2019

Hasil penelitian menunjukan jika manfaat berpengaruh positif terhadap minat menggunakan $e$ money (Gopay). Artinya semakin banyak manfaat yang bisa didapatkan oleh pengguna $e$-money (Gopay), maka minat untuk menggunakan $e$-money (gopay) akan meningkat. Hal ini sesuai dengan teori Theory of Planned Behaviour (TPB), dimana teori ini menjelaskan jika terdapat faktor sebagai dasar hubungan terkait seorang individu memiliki niat dalam penggunaan sistem, yaitu Attitude toward the behavior. Faktor Attitude toward the behaviour menjelaskan sikap individu mengadopsi sesuatu sistem yang dianggapnya positif maka hal tersebut akan dipilih untuk berperilaku dalam kehidupannya. Faktor tersebut dapat menjelaskan faktor perilaku pengguna yang menjelaskan mengenai persepsi pengguna akan menentukan sikapnya dalam penggunaan teknologi. E-Money Gopay dinilai memberikan manfaat yang positif bagi penggunanya sehingga masyarakat memiliki ketertarikan yang tinggi untuk menggunakan teknologi tersebut. Banyaknya manfaat yang ditawarkan oleh e-money (Gopay) membuat minat masyarakat untuk menggunakan e-money (Gopay) tinggi.

Hasil penelitian ini konsisten dengan penelitian yang dilakukan oleh Ozturk (2016). Manfaat/kegunaan berpengaruh positif terhadap minat menggunakan sistem pembayaran elektronik RFID (Radio Frequency Identification) pada industri rumah sakit.

\section{Pengaruh Kemudahan terhadap Minat Menggunakan E-Money (Gopay)}

Hipotesis kedua dari penelitian ini adalah kemudahan berpengaruh positif terhadap minat menggunakan e-money (Gopay) diterima. Hasil ini menunjukkan bahwa kemudahan yang ditawarkan oleh e-money (Gopay) dapat mempengaruhi minat masyarakat untuk menggunakan e-money (Gopay). Semakin mudah penggunaan $e$-money (Gopay) maka akan meningkatkan minat masyarakat untuk menggunakan $e$-money (Gopay).

Hal ini sejalan dengan teori Theory of Planned Behaviour (TPB) yang menyatakan bahwa TPB memiliki faktor Attitude toward the behavior. Faktor Attitude toward the behaviour menjelaskan sikap individu mengadopsi sesuatu sistem yang dianggapnya positif maka hal tersebut akan dipilih untuk berperilaku dalam kehidupannya. Faktor tersebut dapat menjelaskan faktor perilaku pengguna yang menjelaskan mengenai persepsi pengguna akan menentukan sikapnya dalam penggunaan teknologi. Kemudahan pada e-money Gopay memberikan fasilitas pada saat bertransaksi pada pengguna, sehingga masyarakat/pengguna dapat menggunakan teknologi tersebut dengan mudah. Kemudahan pada aplikasi e-money (Gopay) dipandang masyarakat sebagai hal yang positif karena kemudahan tersebut merupakan langkah awal bagi pengguna untuk mendapatkan manfaat dari digunakannya e-money (Gopay).

Hasil penelitian ini konsisten dengan penelitian yang dilakukan oleh Utami \& Kusumawati (2017), yaitu hasil penelitiannya menunjukkan jika kemudahan berpengaruh signifikan terhadap minat mahasiswa dalam menggunakan E-Money, sehingga mereka cenderung memilih untuk menggunakan E-Money.

Pengaruh Risiko terhadap Minat Menggunakan E-Money (Gopay)

Hipotesis ketiga dari penelitian ini adalah risiko berpengaruh negatif terhadap minat menggunakan e-money (Gopay) diterima. Risiko dari e-money (Gopay) dapat mempengaruhi minat menggunakan e-money (Gopay). Semakin tinggi risiko dari e-money (Gopay) maka akan membuat masyarakat kurang tertarik untuk menggunakannya maupun sebaliknya. Hasil penelitian menunjukkan bahwa apabila masyarakat muslim berpersepsi bahwa E-Money Gopay memiliki risiko yang rendah, maka mereka cenderung untuk menggunakan $E$ Money Gopay dikarenakan mereka menilai bahwa E-Money tersebut tidak akan memberikan risiko terhadap uang yang mereka gunakan untuk bertransaksi.

Hasil penelitian ini sesuai dengan teori Innovation Diffusion Theory (IDT) yang berargumen bahwa individu mempunyai level yang berbeda-beda dalam keinginan mengadopsi produk atau layanan inovasi. Dia mengategorikan individu-individu (adopters) ini ke dalam 5 tingkatan berdasarkan orientasi nilai dan motif mereka dalam mengadopsi maupun menolak produk baru. Mayoritas masyarakat tergolong dalam kelompok early majority yaitu kelompok orang-orang yang 
mengadopsi teknologi hanya ketika teknologi tersebut bermanfaat dan telah banyak diapdopsi pengguna lain. Dari sisi kesiapan menanggung risiko kelompok ini lebih berhati-hati. Risiko pada $E$ Money Gopay akan mementukan masyarakat untuk menggunakannya, sehingga masyarakat/pengguna dapat menyeleksi teknologi tersebut apakah akan berisiko dalam jangka pendek dan jangka panjang, sehingga E-Money Gopay sudah didesain untuk meminimalisir risiko yang dapat terjadi pada saat bertransaksi.

Hasil penelitian ini konsisten dengan penelitian yang dilakukan oleh Ozturk (2016). Risiko berpengaruh negatif terhadap niat pasien menggunakan sistem e-money di rumah sakit, artinya sistem e-money disana memiliki tingkat risiko yang rendah. Masyarakat berpersepsi bahwa E-money yang mereka gunakan tidak akan berisko dalam bertransaksi.

\section{Pengaruh Transparansi terhadap Minat Menggunakan E-Money (Gopay)}

Hasil pada penelitian ini menunjukkan jika akuntabilitas tidak berpengaruh terhadap minat untuk menggunakan e-money (Gopay). Akutabilitas yang telah dilakukan oleh Gopay tidak membuat masyarakat tertarik untuk menggunakan e-money (Gopay). Hal ini tidak sejalan dengan teori atribusi yang menjelaskan bahwa perilaku seorang individu disebabkan dari internal atau eksternal. Akuntabilitas adalah bagian dari faktor eksternal yang dapat mempengaruhi minat konsumen untuk menggunakan produk. Akuntabilitas (accountability) dapat dipahami sebagai suatu kewajiban pihak pemegang amanah (agent) untuk memberikan pertanggungjawaban, menyajikan, melaporkan dan mengungkapkan segala aktifitas dan kegiatan yang menjadi tanggungjawabnya kepada pihak pemberi amanah (principal) yang memiliki hak dan kewenangan untuk meminta pertanggungjawaban tersebut. Dari penelitian ini menunjukkan jika akuntabilitas yang telah dibangun oleh gopay tidak membuat masyarakat untuk tertarik menggunakan gopay. Hal ini dikarenakan masyarakat merasa bahwa suatu transaksi harus sesuai dan tidak boleh salah, sehingga masyarakat tidak melihat sisi akuntabilitas sebagai suatu hal yang menarik.

Selain itu, terdapat ketidakkonsistenan dalam jawaban responden. Salah satu contohnya adalah terdapat data responden dimana akutabilitas memiliki kategori rendah dengan skor sebesar 13 (54\%), sedangkan minat menggunakan E-Money Gopay memiliki skor sebesar 25 (78\%) dengan kategori sangat tinggi.

\section{Pengaruh Akuntabilitas terhadap Minat Menggunakan E-Money (Gopay)}

Hipotesis kelima dari penelitian ini yang menyatakan transparansi berpengaruh positif terhadap minat menggunakan E-Money Gopay diterima. Transparansi dari transaksi e-money (Gopay) dapat menarik minat masyarakat untuk menggunakan e-money (Gopay). Semakin transparan transaksi e-money (Gopay) maka peminat e-money (Gopay) semakin tinggi maupun sebaliknya. Hal ini sesuai dengan teori Atribution Theory (Teori Atribusi) yang menyatakan bahwa teori atribusi menyatakan bahwa ketika individu-individu mengamati perilaku seseorang, individu tersebut berupaya untuk menentukan apakah perilaku tersebut disebabkan secara internal atau eksternal. Faktor tersebut berasal dari eksternal pengguna $E$ Money Gopay. Adanya transparansi pada transaksi E-Money Gopay akan meningkatkan minat pengguna untuk melakukan transaksi melalui $E$ Money, sehingga masyarakat/pengguna dapat menggunakan teknologi tersebut dengan aman.

Hasil penelitian ini menunjukkan bahwa tranparansi menggunakan E-Money Gopay berada pada kategori tinggi. Hal tersebut menunjukkan bahwa responden memiliki kecenderungan untuk menggunakan E-Money Gopay karena memiliki tranparansi yang tinggi. Tranparansi dalam bertransaksi memberikan dorongan untuk berperilaku cenderung menggunakan E-Money dalam hal ini Gopay. Berdasarkan hasil penelitian menunjukkan bahwa transparansi yang dimiliki oleh responden sebagian besar jawabannya berada di kategori sangat tinggi sebesar $36 \%$ dan kategori tinggi $64 \%$. Hal tersebut menunjukkan bahwa dapat dikatakan transparansi pada E-Money Gopay oleh masyarakat muslim di Kota Semarang cenderung sangat tinggi.

\section{KESIMPULAN}

Simpulan dari penelitian ini menunjukkan bahwa manfaat, kemudahan dan transparansi berpengaruh positif terhadap minat menggunakan $e$ money (Gopay). Untuk risiko berpengaruh negatif terhadap minat menggunakan e-money (Gopay). Sementara itu, akuntabilitas tidak berpengaruh terhadap minat masyarakat muslim kota Semarang untuk menggunakan e-money (Gopay). Keterbatasan dalam penelitian ini adalah pada sampel penelitian yakni hanya terbatas pada masyarakat muslim di kota Semarang. Penelitian selanjutnya disarankan untuk meneliti faktor-faktor lain yang dapat mempengaruhi minat menggunakan e-money serta memperluas populasi penelitian. Selain itu disarankan untuk mencoba meneliti produk-produk e-money lainnya yang sudah berkembang di masyarakat seperti tap cash (BNI), brizzi (BRI), Flazz (BCA), Link aja , dll.

\section{REFERENSI}

Arvidsson, N. (2014). Consumer Attitudes on Mobile Payment Services - Results From A Proof of Concept Test. International Journal of Bank Marketing, 32(2), 150-170. 
https://doi.org/ 10.1108/IJBM-052013-0048

Djamaluddin, S., Hidayanto, A. N., \& Wardhani, S. (2016). Perception of Beneficiaries Towards Adoption of EMoney in The Distribution of Social Assistance in Indonesia. Economic Journal of Emerging Markets, 8(1), 1324.

https://doi.org/10.20885/ejem.vol8.i ss $1 . a r t 2$

Fong, C. P. C. S. M. W. L. (2016). AsiaPacific Journal of Business. AsiaPacific Journal of Business Administration, 8(1). https://doi.org/http://dx.doi.org/ 10. 1108/APJBA-10-2014-0119

Mahmudi. (2013). Manajemen Kinerja Sektor Publik. Yogyakarta: Sekolah Tinggi Ilmu Manajemen YKPN.

Mardiasmo. (2002). Akuntansi Sektor Publik. Yogyakarta: ANDI.

Nasim, A., \& Romdhon, M. R. S. (2014). Pengaruh Transparansi Laporan Keuangan, Pengelolaan Zakat, Dan Sikap Pengelola Terhadap Tingkat Kepercayaan Muzakki. Jurnal Riset Akuntansi dan Keuangan, 2(3), 550. https://doi.org/10.17509/jrak.v2i3.6 603

Ozturk, A. B. (2016). Customer Acceptance of Cashless Payment Systems in The Hospitality Industry. International Journal of Contemporary Hospitality Management, 28(2), 327-345. https://doi.org/ 10.1108/IJCHM-10-
2014-0510

Ramadhan, A. F., Prasetyo, A. B., \& Irviana, L. (2016). Persepsi Mahasiswa Dalam Menggunakan E-money. Jurnal Dinamika Ekonomi \& Bisnis, 13, 1-15. Diambil dari https://ejournal.unisnu.ac.id/JDEB/ article/view/470/833

Subari, S. M. T., \& Ascarya. (2003). Kebijakan Sistem Pembayaran di Indonesia. (8).

Teoh, W. M.-Y., Chong, S. C., Lin, B., \& Chua, J. W. (2013). Factors Affecting Consumers' Perception of Electronic Payment: An Empirical Analysis. The International Journal of Logistics Management, 2O(1), 97-123. https://doi.org/10.1108/095740909 10954864

Utami, S. S., \& Kusumawati, B. (2017). Faktor-Faktor yang Memengaruhi Minat Penggunaan E-Money (Studi pada Mahasiswa STIE Ahmad Dahlan Jakarta). Jurnal Balance, XIV(2).

Wu, J., Liu, L., \& Huang, L. (2017). Consumer Acceptance of Mobile Payment Across Time: Antecedents And Moderating Role of Diffusion Stages. Industrial Management \& Data Systems, 117(8), 1761-1776. https://doi.org/10.1108/imds-082016-0312 